\title{
Structural Constraint of Social Rehabilitation Children in Conflict with Law: Study At Children Care Institution of Bina Remaja Budi Utama Lubuk Alung
}

\author{
Prike Agusti Ningrum ${ }^{1}$, Elfitra2 ${ }^{2}$, Bob Alfiandi ${ }^{3}$ \\ \{ prikeningrum11@gmail.com ${ }^{1}$ \} \\ Department of Sociology, Universitas Andalas, Padang, Indonesia
}

\begin{abstract}
A social rehabilitation program for children in conflict with law is an effort of the government to fulfill the basic rights of those children during the determination process at Children care Institution of Bina Remaja Budi Utama Lubuk Alung. However, there are some problems found in a rehabilitation program. This research aimed to investigate the problems in rehabilitating children in conflict with the law. The theory used was based on Anthony Giddens theory in which focuses on double relationships between agent and structure. This research was conducted by using double hermeneutics as a sub-type of the qualitative research. This article showed that the problem faced by the Children care Institution of Bina Remaja in rehabilitating children in conflict with the law were the lack of human resources, the lack of the financial budgeting for this program, unsupported facilities, the lack of experience in handling children in conflict with the law.
\end{abstract}

Keywords: Children in Conflict with Law, Social Rehabilitation, Structural Constraints, Agent, Relation of Agent Structure.

\section{Introduction}

The Republic of Indonesia has ratified the Convention on the Rights of the Child through Presidential Decree (Keppres) no. 36 of 1990. This ratification is as a government's effort to protect children. From the various issues that are existed in the Convention on the Rights of the Child, one of which is in great need of special attention such as children against the law which can be abbreviated as ABH. Referring to the Law No. 11 the Year 2012 on the Criminal Justice System for Children, the definition of ABH is a child who became the perpetrator of criminal acts, victims of criminal acts, and children who witnessed a crime. ABH is a child, who has been 12 (twelve) years old, and under 18 (eighteen) years old who allegedly committed a crime.

Children, who are a trust from God and is a strategic asset of the nation, deserve special attention and given the greate possible opportunity to grow and develop naturally, physically, psychologically and socially. In a sociological review, ABH can be categorized as a deviant or misbehaving child ( Share Social Work Journal, Vol. 5, Number 1, Page 36, ISSN: 2339 -0042). $\mathrm{ABH}$ is an individual who deviates from values and norms in society. Behaviour is a behavior that is not by norms and values in society. So ABH must get special attention so that deviant behavior does not happen again. The impact of the lack of special attention to children will lead to social problems that deviate such as criminal involvement such as $\mathrm{ABH}$, drug abuse and other social matters. It is, therefore, necessary to have an institution that can deal with $\mathrm{ABH}$ problems without having to neglect their rights as a child. 
Placing children as perpetrators of crime certainly brings considerable consequences regarding child growth and does not make children deterrent or become a better person; prison often makes children more professional in committing criminal acts (Joni et al. 1999: 1). The punishment process at Penal Institution can have a negative impact on the child. The negative impact of the punishment process experienced by the child is psychologically as well as socially. Once the punishment process is over, the child's problem will not stop by itself. Labeling (stigma) by poor people to children who are sentenced is a problem in itself. After release from the rison, children are alienated by the social environment, the playing environment, and the family environment. It can cause children to feel alienated and outcast from their social environment. Such a condition is far from fulfilling the rights of the child. It thus shows that prison is not a good place for $\mathrm{ABH}$.

The $\mathrm{ABH}$ case in Indonesia has increased in the last five years. In the last five years, there are about 6,147 children who have legal cases. In 2011, the number of ABH was 695 children, then in 2012 increased to 1,413 and in 2013 to 1,428 cases. That number continued to increase to 2,208 cases in 2014, and until July 2015 cases of ABH amounted to 403. Then, the number of cases of children with problems with pornography and cyber criminality over the last five years in total is 1,111 [1].

From the nine clusters of KPAI complaints, ABH case places the highest position. As of April 2015, there were 6,006 cases of ABH. Problems of upbringing reached up to 3,160 cases, education 1,764 cases, the health of NaPZa (Narcotics, Psychotropic, and other addictive substances) 1,366 cases and cybercrime or pornography reached 1,032 cases. Based on these data, it can be seen that in 2015 , the $\mathrm{ABH}$ case is at a fairly high rate from other case data in KPAI [2]

In accordance with the principle of legal protection of children, it should conform to the Convention on the Rights of the Child (Convention on the Rights of the Child) which has been ratified by the government of the Republic of Indonesia by Presidential Decree No. 36 of 1990 on the Ratification of the Convention on the Rights of the Child. Law No. 3/1997 on Juvenile Court is intended to protect $\mathrm{ABH}$ so that children can meet their long-term future and give an opportunity to the children so that through coaching will be obtained their identity to become self-reliant, responsible, and self-supporting people, family, community, nation, and state. However, in the implementation, the children are positioned as objects, and the treatment of $\mathrm{ABH}$ tends to harm the child. In addition, the law is no longer appropriate to the legal needs of the community and has not comprehensively protected $\mathrm{ABH}$. Therefore, the government established law No. 11 of 2012 on the Children Criminal Justice System. Referring to Law No. 11 of 2012, handling efforts that should be done for the ABH is to undergo social rehabilitation in the institution of social welfare of $\mathrm{ABH}$. This institution is expected to be able to fulfill the interests and rights of children during rehabilitation and to restore physical and psychological condition due to the problems they face. The social rehabilitation is the process of refunctionalization and development to enable one to be able to carry out its social functions fairly in the life of the community. Therefore the process of social rehabilitation for ABH is very important as a coaching effort for $\mathrm{ABH}$.

By the mandate of Law Number 11 the Year 2012, ABH starts from the investigation process until there is a permanent legal decision for subsequent social rehabilitation in $\mathrm{ABH}$ Social Welfare Institution (LPKS). In its implementation, LPKS ABH, one of them is managed by LPKS manager who is the board and companion of $\mathrm{ABH}$ which are supporting the implementation process of social rehabilitation of $\mathrm{ABH}$. All managers of this institution work together to undertake the $\mathrm{ABH}$ administration and keep monitor the process of implementing the social rehabilitation of $\mathrm{ABH}$ (ABH Service Operational Standards). West Sumatra is one of 
the provinces in Indonesia that are vulnerable to ABH cases. Based on data obtained from Head of BIN OPS Division of General Criminal Act of West Sumatra Regional Police Headquarters, there is an increasing number of ABH from 2014-2016. They are 171 cases in 2014, 288 cases by 2015 and there are 200 cases until September 2016 [3]. From the data, it can be seen the most dominant cases of ABH occurred in 2015 and 2016.

$\mathrm{ABH}$ by the SPPA Act needs to do social rehabilitation to restore physical and psychological conditions due to the problems they face. The social rehabilitation is the process of re-functionalization and development to enable one to be able to carry out its social functions fairly in the life of the community. Therefore, the process of social rehabilitation of $\mathrm{ABH}$ is very important as a coaching effort for ABH. Since 2015, ABH in West Sumatra underwent a social rehabilitation process at the Children's Social Institution of Bina Remaja Budi Utama Lubuk Alung. Children's Social Institution of Bina Remaja Budi Utama Lubuk Alung from now on can be abbreviated with PSAABR. By Minister of Social Decree Number 44 / Huk / 2015, PSAABR is used as a place of social rehabilitation for ABH. PSAABR is the Regional Technical Implementation Unit (UPTD) under the auspices of the Social Service of West Sumatra Province. PSAABR conducts guidance to children from underprivileged families and out-ofschool drop-outs that need skills. In addition, this institution also accommodates children assisted who are undergoing punishment for rehabilitation. Until now, PSAABR has developed $\mathrm{ABH}$ for 12 people of $\mathrm{ABH}$ from 2015, and in 2017 there are still $3 \mathrm{ABH}$ people who fostered with diverse cases.

As the implementation of SPPA and Minister of Social Decree no. 44 / Huk / 2015, it should rehabilitate the social handling of ABH in PSAABR runs optimally as mandated by the Act. However, based on preliminary findings, the reality is that there are problems and obstacles faced by PSAABR in the handling of $\mathrm{ABH}$ so that to overcome these obstacles PSAABR managers have their own efforts done in the process of social rehabilitation of the handling of $\mathrm{ABH}$ in PSAABR done in patterned and repeated.

Constraints and efforts that occur is a unity of interrelated processes in achieving goals. In this study will focus on the constraints and efforts made in the social rehabilitation of $\mathrm{ABH}$. This research is important to do because it identify the obstacles and efforts made by all managers of PSAABR in the process of implementing social rehabilitation of ABH handling $\mathrm{ABH}$ in overcoming all obstacles and problems that exist either from the aspect of $\mathrm{ABH}$ or from the aspect of PSAABR itself. Thus, it will show how the interaction between PSAABR managers against $\mathrm{ABH}$ in handling obstacles in the process of social rehabilitation in PSAABR which is formed in a series of social practices conducted by the police officers and repeated in different times and times. Therefore, from the background above, the authors were interested to identify what the constraints of handling ABH in PSAABR are.

Based on the above problem formulation, this study aims to determine the constraints in the social rehabilitation of $\mathrm{ABH}$ in PSAABR. While the benefits of this research theoretically (academically) contribute to the students in completing the study leading to the development of science related to the social rehabilitation program of $\mathrm{ABH}$ which is mainly concerning on social practices of handling ABH in PSAABR. As well as practical results of this study can provide input for policymakers to evaluate $\mathrm{ABH}$ social rehabilitation program regarding both managers and institutions for better implementation. 


\section{Methods}

The implementation of this research was 6 months, started from January to May. The location of this research was conducted at Child Social Institution of Bina Remaja (PSAABR) Budi Utama Lubuk Alung, Kabupaten Padang Pariaman. This study used primary and secondary data. Primary data collection was using interview guidance of informants and secondary data was obtained from related institutions. This study used a dual hermeneutical approach by Anthony Giddens [4]. Double hermeneutics is initiated by Anthony Giddens who is one of the qualitative research subtypes. The Giddens method, based on a philosophy which believes that the phenomenon of social theory study is action and interpretation, that man (agent/actor) acts on the consciousness and interpretation of his actions and the actions of others; that theory is constructed through the interpretation of research on the interpretation of the action of the agent (actor) researched.

\section{Result and Discussion}

From the research, which was conducted for 6 months, it found the following results:

The research was conducted at Child Social Institution of Bina Remaja (PSAABR) Budi Utama Lubuk Alung, Kabupaten Padang Pariaman. The results of the study explain that PSAABR managers are experiencing difficulties in the rehabilitation process of $A B H$ and the efforts made by PSAABR managers to overcome the existing constraints in the rehabilitation process of $\mathrm{ABH}$.

In Structural Theory proposed by Anthony Giddens, the existence of relationships is a duality between agents and structures. In this study, the agency is the manager of PSAABR, the board, and companion of $\mathrm{ABH}$, while the structure is the rules that exist in the social rehabilitation of $\mathrm{ABH}$. So the relationship is a duality (the process of mutual influence) between the managers PSAABR (agent) with the structure. The obstacles encountered in ABH social rehabilitation are:

\subsection{Lack of Human Resources}

Human resources (HR) are one factor that is very important even cannot be separated from an organization, both institutions, and companies. Human resources are also the key that determines the development of the company. In essence, human resources are human beings employed in an organization as drivers, thinkers, and planners to achieve the organization's goals. In general, the definition of human resources is an individual who works as a driver of an organization, both institutions and companies and serves as an asset that must be trained and developed the ability.

A sufficient number of human resources can empower PSAABR managers in conducting social rehabilitation of $\mathrm{ABH}$, whereas an adequate amount of task division managers i.e. $\mathrm{ABH}$ companion can be run well. In reality, however, in the social rehabilitation of $\mathrm{ABH}$, the number of human resources is inadequate given the number of $\mathrm{ABH}$ counterparts, such as a social worker who only 4 people, no skill counselor and one nurse. Based on the SOP of ABH, the supervisor consists of 5 people social worker, 2 nurses, 2 skill counselors and 1 religious counselor. This shows the agent's inhibiting structure that is the $\mathrm{ABH}$ companion in doing $\mathrm{ABH}$ social rehabilitation. 


\subsection{Lack of Budget Funds For ABH}

In addition to the lack of human resources, the handling of $\mathrm{ABH}$ should be supported with sufficient budget funds. But in reality, the PSAABR budget for ABH is very limited. The existing budget only focuses on the principal PSAABR program that is for foster children and skill only. However, based on the rules governing the funding in the SOP, every once a month should address the disbursement of funds for the needs of $\mathrm{ABH}$.

Adequate budget funds can empower managers to rehabilitate social $\mathrm{ABH}$, where with sufficient budgetary amount of time the needs of $\mathrm{ABH}$ will be met. However, in reality, the budget for $\mathrm{ABH}$ is very limited. The existing budget only focuses on the PSAABR program to foster only children physical, vocational and religious skills. This shows the structure of inhibiting agents in doing $\mathrm{ABH}$ social rehabilitation.

\subsection{Insufficient Infrastructure and Facilities}

Infrastructure and facilities at PSAABR to support ABH social rehabilitation process in SOP are stated that there are skill activities held to support ABH activities such as the availability of buildings for special skill activities for $\mathrm{ABH}$ and their skill tools and for sports activities, available places or fields that support sports activities and complete equipment. However, the reality, equipment and places for skills and sports activities are only superimposed with other foster children. Building skills and equipment as well as the building and sports equipment is not adequate and not intended specifically for $\mathrm{ABH}$. The skill building is only one for child skills only and not for $\mathrm{ABH}$.

Sufficient infrastructure and facilities can empower managers in conducting ABH social rehabilitation, where with adequate infrastructure and facilities it will support the activities of $\mathrm{ABH}$ every day. However, in fact, infrastructure and facilities are inadequate regarding the insufficient number of tools for sport and its place and the absence of tools focused on $\mathrm{ABH}$ skills and the building. This shows the structure of inhibiting agents in doing $\mathrm{ABH}$ social rehabilitation.

\subsection{Lack of Understanding Related to ABH Social Rehabilitation}

Under Law Article 1 Paragraphs 14 and 15 stipulating that PSAABR managers, especially $\mathrm{ABH}$ social welfare workers, should have competence and knowledge related to social rehabilitation for $\mathrm{ABH}$ in $\mathrm{ABH}$ social welfare institution (LPKS). Ideally based on SOP, each $\mathrm{ABH}$ companion is given training at least once a year so it can improve the understanding of the $\mathrm{ABH}$ companion in the social rehabilitation of $\mathrm{ABH}$. However, in reality, $\mathrm{ABH}$ companions, such as religious caregivers and counselors, have not been trained and so far only on the part of stakeholders and social workers only whereas the daily face to face with $\mathrm{ABH}$ is the religious caregiver and mentor. Knowledge Related to ABH Social Rehabilitation needs to be done for the implementation of social rehabilitation program of $\mathrm{ABH}$ maximally.

Training related to $\mathrm{ABH}$ social rehabilitation to improve understanding of $\mathrm{ABH}$ companion can empower the manager who is $\mathrm{ABH}$ companion. However, in reality, training is only for civil servants and social workers only. It suggests that the structures inhibit agents in social rehabilitation for $\mathrm{ABH}$.

The theoretical contribution to the problem of $\mathrm{ABH}$ handling should be observed from two sides: the manager of PSAABR who is consisting of the board and the ABH companion as agents and rules that exist in the social rehabilitation of $\mathrm{ABH}$ as a structure. To overcome the obstacles in the social rehabilitation of $\mathrm{ABH}$, it is important to note not only the agency's capabilities but also the applied rules in the $\mathrm{ABH}$ social rehabilitation associated with the resources required at PSAABR. 


\section{Conclusion}

Based on the result of the research, it can be concluded that the constraints faced by PSAABR managers in ABH social rehabilitation are related to human resources, budget and infrastructure. The constraints faced by PSAABR managers in ABH social rehabilitation are lack of human resources, lack of budget for $\mathrm{ABH}$, inadequate facilities and infrastructure, and lack of understanding related to $\mathrm{ABH}$ handling.

\section{References}

[1] (http://www.solopos.com).

[2] (http://news.metrotvnews.com).

[3] Interview with Petrus Canisius, October 20, 2016).

[4] Giddens, Anthony. 1984. The Constitution of Society. Outline of the Theory of Structuration. Cambridge: Polity 